\title{
Why Nations Fail. The Origins of Power, Prosperity, and Poverty
}

\author{
Oskar Kurer
}

\author{
Institute of Economics, University of Erlangen-Nuremberg, Kochstraße 4, 91054 Erlangen
}

The whole field of economics probably does not include a book more ambitious, going well beyond Adam Smith in its attempt to explain the rise and decline of the wealth of nations. And, like Smith, its views are presented with the help of brilliant applications of the theoretical structure, ranging over millennia and spanning innumerable cultures. These illustrations make the book a thoroughly enjoyable reading experience.

The explanation for the rise and decline of nations is intriguingly simple. "Inclusive" economic and political institutions are responsible for an ascendency and "extractive" institutions for stagnation and fall.

In the main, inclusive economic institutions are equated to well-regulated markets with a high degree of security of property where competition enforces the dynamics of economic change through the process of creative destruction. The authors thus take the well-established path that "good governance" is a necessary condition for economic success and that "extractive institutions" in the shape of monopolization, crony capitalism and the plundering of state resources are responsible for economic failure.

Under what conditions do "inclusive economic institutions" or "good governance" emerge? To this perhaps most difficult question in field of economic development the authors give another simple answer: inclusive political institutions and centralization. Centralization does not stand for what it usually means, but for an effective public administration, a prerequisite for the enforcement of property rights and the implementation of market-friendly policies. More controversial is the notion that "pluralism" causes "inclusive economic institutions". Pluralism prevails where "political institutions" "distribute power broadly in society" and subject political power to constraints. This diffusion of power provides a barrier, so the argument goes, to the emergence of "extractive economic institutions". On the other hand, the "absolutism" of Spain in the $17^{\text {th }}$ century of Russia and Austria-Hungary in the $19^{\text {th }}$ century or of African dictatorships in the $20^{\text {th }}$ century is governed by "extractive" political and economic institutions.

Extractive institutions have tendency to persist because of "vicious circles"; politicians in power have an incentive to maintain a predatory economic system that is the source of

*Address correspondence to this author at the Institute of Economics, University of Erlangen-Nuremberg, Kochstraße 4, 91054 Erlangen; Tel: 09131 207058; Fax: 00499131 8522060;

E-mails: Oskar.Kurer@wiwi.phil.uni-erlangen.de; kurer@gmx.de their political power and wealth. Even political upheavals independence, revolutions or coups - often only lead to a replacement of the personnel running the system but not of the institutions; the new rulers rapidly adapt to the system of parasitism and exploitation. With the aid of "vicious circles" the authors trace the establishment of "extractive institutions" a long way back, to "critical junctures". The Spanish colonization of much of Latin America is such a critical juncture by creating a political-economic system with predatory governments that survived to the present day at least in some countries like Guatemala.

Opposed to the "vicious circles" are the "virtuous circles" where pluralism and inclusive policies reinforce each other. These too have roots in major events of the remote past. It is suggested that without the critical junctures of Magna Charta and the Glorious Revolution of 1688, both promoting forms of pluralism that prevented the predatory economic policies of absolutism, the Industrial Revolution in Britain would not have occurred.

One of the weaknesses of this account is the exclusion of culture from the story of secular economic change. The justification for the irrelevance of culture lacks persuasion. More sophisticated versions of institutionalism accept that values, norms and beliefs about how the world operates are independent factors that shape economic development. ${ }^{1}$ Ideal influences impact on economic and political behavior directly through factors like social trust as well as indirectly by shaping formal institutions. Indeed, one of the more plausible explanations for the relative decline of Islamic countries prior to the Industrial Revolution holds that the Islamic legal system froze institutions like commercial and inheritance laws and in the process prevented the rise of efficient economic organizations. ${ }^{2}$

Equally, it is too facile to associate "absolutism" with predatory economic institutions. Singapore's rule by a coterie around the Lee family that governs with the help of brute force and the manipulation of the media did achieve a standard of living that belongs to the highest in the world.

A further difficulty in the analysis is the absence of a clear-cut definition of what constitutes "inclusiveness". Is Papua New Guinea pluralist, with its predatory economic system, its vibrant democracy, broad representation and at -

\footnotetext{
${ }^{1}$ Douglass North. 1990. Institutions, Institutional Change and Economic Performance. Cambridge University Press

${ }^{2}$ Timur Kuran. 2010. The Long Divergence: How Islamic Law Held Back
} the Middle East. Princeton University Press. 
least until recently - judicial restraints on political power? Is Greece not a country with inclusive institutions? Indeed, there is little reason to believe that inclusive political institutions prevent anti-market policies.

Moreover, the analysis operates with a particular method of reduction of complexity: the distinction between "critical junctures" that are worthy of attention and "contingencies" that fall outside the purview of analysis. This separation leads to a peculiarly distorted view of historical processes. For example, only by excluding just about everything else that prevented the emergence of inclusive political and economic institutions in the two hundred year history of independent Latin America can the fashionable stress on the importance of colonization and slavery as causes of its cur- rent economic woes be maintained. Such speculations become more dubious the remoter an event as it becomes impossible to assess what would have happened in its absence.

In the end, Acemoglu and Robinson have made a persuasive case that institutions are decisive for economic success. The great question what political conditions make for institutionalization or institutional decay remains obscure as ever. Indeed, it is very likely that no general answer is to be found - the conditions that contribute to it are too complex. If that is the case, economic success of a single country is caused by a series of random events; the process of economic growth worldwide resembles a random walk with some drift as more countries emerge with appropriate institutions for economic growth.

Received: February 07, 2012

Revised: March 02,2012

Accepted: March 17, 2012

(c) Oskar Kurer; Licensee Bentham Open.

This is an open access article licensed under the terms of the Creative Commons Attribution Non-Commercial License (http://creativecommons.org/licenses/by-nc/3.0/) which permits unrestricted, non-commercial use, distribution and reproduction in any medium, provided the work is properly cited. 